\title{
MODALITAS TUTURAN MAHASISWA DALAM PRESENTASI
}

\author{
Rizka Hayati ${ }^{1)}$, Ida Ayu Panuntun ${ }^{2)}$ \\ ${ }^{1,2}$ Fakultas Keguruan dan Ilmu Pendidikan, Universitas Pekalongan \\ Email: ${ }^{1}$ rizkalinguistik@gmail.com, ${ }^{2}$ ayyu_idda@yahoo.com
}

\begin{abstract}
Modality in semantics can be said as speaker's expression reflected in his or her word choices. This article took modality as the main theme because modality can explain someone's expression or belief about what is being conveyed. The use of modality which shows speaker's expression can be seen in the classroom presentation class. Each student will have different choice in using modality. Actually there are types of modality. Those are intentional, epistemic, deontic, and dynamic. This study aimed to explain the types of modality used by students in explaining the material and expressing their opinions during presentations in class. The method used was descriptive qualitative. The data were collected by using observation. After the data were collected, it was analyzed by using some stage, those were identification, classification, description and interpretation. From the results of the analysis, it can be concluded that the modality used by students in expressing their opinions during presentation class was intentional modality, epistemologi modality, dynamic modality, and deontic modality.
\end{abstract}

Keywords: Modality, types of modality, utterances, classroom presentation,

\section{PENDAHULUAN}

Komunikasi merupakan alat bantu utama dalam menuangkan dan bertukar ide antar sesama individu. Menurut Sari (2017) komunikasi adalah sebuah istilah yang berasal dari bahasa asing "communicates" yang berarti berbagi atau milik bersama. Berbagi dan milik bersama adalah sebuah konsekuensi besar yang timbul sebagai akibat salah satu peran individu sebagai makhluk sosial. Selain pernyataan di atas definisi komunikasi juga dapat diperoleh dari pernyataan Wiryanto, (2004), komunikasi adalah "bersama-sama atau common." Berdasarkan pernyataan para pakar di atas, maka dapat disimpulkan bahwa komunikasi adalah sebuah media dalam bertukar pikiran yang dilakukan secara bersama-sama antar makhluk hidup.

Berbicara merupakan bagian yang sangat erat dengan pokok kajian dalam sebuah komunikasi. Berbicara adalah suatu proses penyampaian informasi melalui kata-kata. Dalam pelaksanaannya, berbicara selalu diikuti sebuah ekspresi. Ekspresi tersebut dikenal dengan sebutan modalitas. Menurut Risaldi
(2021) modalitas adalah sebuah bentuk bahasa dalam mewujudkan lindung nilai dan empatik yang dikenal juga sebagai penanda kepastian untuk menunjukkan tujuan atau keinginan dari penulis sebagai penanda kepastian yang digunakan untuk mengungkapkan kemungkinan atau kebenaran dari beberapa konten proposisional dan sebagai penunjuk komitmen. Sejalan dengan pernyataan Risaldi, dkk, maka Kumalasari (2020) menuturkan bahwa modalitas berarti sebuah keterangan yang terdapat dalam sebuah kalimat sehingga keterangan tersebut mempunyai fungsi untuk menyatakan sikap dari pembicara terhadap halhal yang sedang dibicarakan, baik berupa perbuatan, peristiwa, keadaan ataupun sikap.

Berdasarkan pernyataan di atas, maka dapat disimpulkan bahwa modalitas adalah ekspresi pembicara mengenai keyakinan dan sikap atau kehendak dan kekuasaan terhadap keberadaan, keadaan, hubungan, atau sesuatu. Modalitas disadari atau tidak biasanya tampak ketika seseorang berbicara. Ekspresi pembicara akan selalu ada dalam tindak tutur atau ucapan seseorang. Modalitas dalam bahasa seorang 
penutur dipengaruhi oleh dan merefleksikan pemikiran si pengujar.

Modalitas sering muncul sebagai ekspresi dalam berbagai bentuk komunikasi, sebagai contoh pada sebuah kegiatan diskusi dan presentasi. Presentasi mahasiswa di dalam kelas menuntut mahasiswa untuk mampu berpendapat dan mempertahankan pendapat. Menurut pernyataan Desi (2017), presentasi merupakan sebuah cara dalam menyampaikan informasi, gagasan, ide atau pesan kepada audiens. Cara penyampaiannya adalah dengan menjelaskan atau lebih tepatnya menguraikan informasi tersebut secara jelas dan terstruktur. Hal ini dilakukan supaya maksud dan tujuan informasi tersebut dapat tersampaikan sebagaimana harapan dari para pembicara. Berdasarkan pernyataan di atas, maka dapat disimpulkan bahwa presentasi mahasiswa di kelas dapat menjadi media untuk mengeluarkan pendapat dan pemberi informasi sekaligus penyalur aspirasi, menjadi tempat yang bagus untuk memberi opini-opini tentang keilmuan yang sedang dibahas atau hal-hal di sekitar yang terjadi. Dengan menyampaikan pendapat lewat presentasi kelas, hasil dari opini seseorang akan lebih mudah didengar dan mendapat tanggapan dari masyarakat. Maksud presentasi tentu saja agar ide dalam tulisannya dapat diakses oleh orang lain, tetapi juga berharap orang akan mengikuti dan mendukung pendapatnya.

Berbicara mengenai modalitas pasti tak lepas kaitannya dari kategori gramatikal. Gramatikal kategori seperti kita ketahui termasuk di dalamnya pembahasan mengenai tense atau kala, aspektualitas, modalitas, gender, sex. Pengkajian modalitas mengacu pada linguistik modalitas, yaitu mengenai bagaimana dunia itu dan bagaimana dunia seharusnya. Hal ini dapat merupakan suatu kesimpulan dari pendapat personal ataupun opini pribadi.

Dalam kelas presentasi, banyak mahasiswa mencoba untuk menyatakan pendapatnya, oleh karena itu peneliti mencoba mengangkat hal tersebut karena terdapat banyak opini yang mengkritisi masalah ini. Dari sini peneliti akan mengangkat tema modality yang terdapat dalam tuturan mahasiswa saat presentasi.

Pemahaman akan situasi yang terjadi akan lebih dimengerti saat kita menggunakan gramatikal kategori untuk menganalisisnya. Gramatikal kategori meliputi kajian mengenai kala, aspek dan modal. Ketiga kajian tersebut membantu kita dalam mendeskripsikan suatu situasi. Sebagai dasar secara singkat, berikut pengertian tentang kala: "Tense relates the time of situation referred to to some other time, usually to the moment of speaking" (Comrie, 1976). Sedangkan pengertian aspek adalah sebagai berikut: "Aspect is different way of viewing the internal temporal constituency of a situation. Aspect is qutite different from tense. It is in the sense of oppositions as that between perfective and imperfective or telic and atelic". Yang ketiga adalah modalitas. Sebagai bagian dari kategori gramatikal, modalitas selalu berhubungan dengan tense/kala, aspektualitas, gender, atau sex. Sehingga pembahasan modalitas tentu tidak pernah lepas dari hal-hal tersebut. Misalnya, tentang kala, dalam kala kita membahas tentang kapan waktu saat keadaan yang dibicarakan oleh pembicara terjadi. Di dalam kala ada 3 aspek yang dilihat, yang pertama adalah past atau yang telah terjadi, lalu waktu sekarang atau present, yang terakhir adalah yang akan datang atau future. Dalam penggunaan kala tak lepas dari mood pembicara atau penulis dalam mengomentarinya. Keyakinan bahwa sesuatu terjadi sekarang, yang lalu atau akan terjadi kemudian menunjukkan modalitas keyakinan pembicara akan keadaan yang diketahuinya. Sedang hubungan modalitas dengan aspek adalah dalam aspek dibahas mengenai perfektif dan imperfectif, sesuatu telah terjadi dengan komplet, ada awalan, proses, dan akhiran, ataukah kejadian itu menandakan habitual. Modalitas dari pembicara atau penulis tentu mempengaruhinya.

Menurut Saeed (2000), modalitas adalah istilah yang mengacu pada piranti yang memungkinkan penutur untuk mengungkapkan derajat/tingkatan komitmen atau kepercayaan terhadap suatu proposisi. Dari pengertian di atas maka dapat disimpulkan bahwa modalitas 
digunakan untuk mengungkapkan sikap, komitmen, atau kepercayaan terhadap suatu hal. Sebagai tambahan, istilah modalitas (modality) digunakan untuk mengacu pada fungsi, sedangkan mood mengacu pada bentuk gramatikanya (Palmer, 1981). Masih tentang pengertian modalitas, menurut Chaer (1994) menyatakan bahwa yang dimaksud dengan modalitas adalah keterangan dalam kalimat yang menyatakan sikap pembicara terhadap hal yang dibicarakan, yaitu mengenai perbuatan, keadaan, peristiwa, atau sikap terhadap lawan bicaranya. Sikap ini dapat berupa pernyataan kemungkinan, keinginan, atau keizinan. Dalam Bahasa Indonesia, modalitas dinyatakan secara leksikal. Menjelaskan bahwa modalitas adalah:

a. Klasifikasi proposisi menurut hal menyuguhkan atau mengingkari kemungkinan atau keharusan.

b. Cara pembicara menyatakan sikap terhadap situasi dalam suatu komunikasi antar-pribadi.

c. Makna kemungkinan, keharusan, kenyataan yang dinyatakan dalam kalimat.

Dalam Bahasa Inggris modalitas dapat terlihat dengan jelas karena dinyatakan menggunakan modal (may, can, should, etc), dan juga melalui kalimat pengandaian. Dalam Bahasa Indonesia modalitas dinyatakan dengan kata-kata seperti barangkali, harus, akan atau dengan adverbial kalimat seperti pada hakikatnya, menurut hemat saya. Seperti dalam contoh berikut: "Barangkali kasus ini harus di bawa ke meja hijau"; "Kita harus tegas menindak para pelanggar hukum".

Dalam Bahasa Inggris ada beberapa macam modalitas, seperti modalitas epistemik, modalitas deontik, modalitas dinamik, modalitas alethik. Sedang dalam Bahasa Indonesia terdapat jenis-jenis modalitas seperti dalam uraian dibawah ini.

\subsection{Modalitas Intensional}

Modalitas intensional adalah modalitas yang menyatakan keinginan, harapan, permintaan, atau ajakan. Modalitas ini ditandai dengan unsur leksikal seperti ingin, mau, tolong, mari, ayo, dan silakan. Contoh:

a. Saya ingin dapat berguna bagi orang lain.

b. Adik mau makan. c. Tolong agar sampah-sampah yang berserakan dibersihkan

d. Mari belajar bersama!

e. Ayo bekerja dengan penuh semangat.

f. Silakan buka buku anda halaman 100 .

\subsection{Modalitas Epistemik}

Modalitas epistemik adalah modalitas yang menyatakan kemungkinan, kepastian, dan keharusan. Modalitas ini ditandai dengan unsur leksikal seperti mungkin, bisa jadi, pasti, belum pasti dan harus. Contoh:

a. Dia mungkin takkan datang lagi ke sini setelah kejadian itu.

b. Bisa jadi orang tadi marah-marah karena diperlakukan secara tidak adil.

c. Saya pasti bisa melewati semua hal yang membingungkan ini.

d. Belum pasti mereka menerima keadaan ini dengan ikhlas.

e. Makalah ini harus dibuat sebagai salah satu syarat kelulusan.

\subsection{Modalitas Deontik}

Modalitas deontik adalah modalitas yang menyatakan keizinan atau keperkenanan. Unsur penandanya adalah unsur leksikal seperti izin dan perkenan. Contoh:

a. Saya mohon izin untuk tidak menghadiri rapat malam ini karena ada urusan keluarga.

b. Atas perkenan dirinya, saya boleh membantunya.

\subsection{Modalitas Dinamik}

Modalitas dinamik adalah modalitas yang menyatakan kemampuan. Unsur penandanya dapat berupa unsur leksikal dapat, bisa, dan mampu. Contoh:

a. Semua murid dapat mengerjakan soal ujian dengan baik dan benar.

b. Semua hal akan bisa terjadi jika kita punya kemauan dan semangat dalam mengerjakan.

c. Dia татри menyelesaikan S3-nya dalam waktu tiga tahun.

Berdasarkan uraian tersebut di atas, untuk memahami suatu situasi diperlukan aspektualitas, temporalitas, dan modalitas. Modalitas menduduki posisi yang penting dalam memahami situasi karena ketiganya dapat menjelaskan sikap pembicara dan hubungannya dengan peristiwa, keadaan, atau 
proses yang diungkapkan oleh verba. Dari penjelasan mengenai modalitas di atas, peneliti mengambil rubrik opini sebagai bahan dan data untuk menganalisis.

Berkaitan dengan judul penelitian ini, peneliti menggunakan beberapa artikel penelitian pendukung yang memberikan kontribusi positif dalam penelitian ini. Adapun artikel penelitian tersebut adalah penelitian yang dilakukan oleh Aisyah (2019) dengan judul Modalitas Bahasa Indonesia dalam Talk Show Mata Najwa. Berdasarkan artikel tersebut dapat diperoleh informasi bahwa bentuk modalitas yang paling sering digunakan dalam Talk Show Mata Najwa pada topik debat dan diskusi adalah modallitas epistemik.

\section{METODE PENELITIAN}

Metode yang digunakan dalam penelitian ini adalah deskriptif kualitatif. Deskriptif adalah suatu pendekatan penelitian yang mempunyai tujuan untuk mendeskripsikan suatu kejadiaan atau kegiatan tertentu, mendeskripsikan orang dan perilakunya, serta peristiwa di lapangan dengan rinci dan juga mendalam (Faisal, 1992). Terlebih lagi, Bogdan dan Taylor (1975:5) dalam Moleong (1999) menyatakan bahwa metode kualitatif adalah suatu metode yang menghasilkan data deskriptif, data tersebut berupa ujaran lisan dan kata-kata tertulis dari orangorang, kejadian, atau perilaku yang diamati. Dari kutipan di atas, deskriptif kualitatif adalah suatu metode penelitian yang mencoba mendeskripsikan orang serta perilakunya dengan rinci dan mendalam untuk menghasilkan suatu deskripsi berupa deskripsi ujaran atau perilaku dari subjek penelitian.

Data dalam penelitian ini adalah data kualitatif, yaitu berupa ujaran yang dituturkan oleh mahasiswa dalam menyampaikan pendapat dan mejelaskan materi saat melakukan presentasi di dalam kelas. Subjek penelitian adalah 11 mahasiswa yang melakukan presentasi di dalam kelas. Saat presentasi, mahasiswa menjelaskan materi dan menyampaikan pendapat.

Dalam metode penelitian kualitatif, terdapat beberapa cara mengambilan data, yaitu metode simak dan metode cakap (Sudaryanto, 2015). Lebih lanjut, Sudaryanto (2015:203) menyatakan bahwa metode simak adalah metode pengambilan data dengan cara menyimak penggunaan bahasa pada objek atau subjek yang diteliti. Langkah selanjutnya adalah metode catat, yaitu mencatat data dengan alat tulis atau instrumen tertentu. Dalam metode pengumpulan data ini, peneliti menggunakan lembar observasi sebagai instrumen. Setelah data diambil, data kemudian dianalis secara kualitatif. Langkah-langkah analisis data adalah identifikasi data yaitu mengidentifikasi modalitas dalam tuturan mahasiswa. Selanjutnya adalah klasifikasi data, yaitu klasifikasi modalitas ke dalam jenisjenisnya. Langkah selanjutnya adalah deskripsi dan interpretasi, yaitu menjelaskan realitas data berdasar teori, yang terakhir adalah membuat simpulan.

\section{HASIL DAN PEMBAHASAN}

Peneliti mengambil data penelitian dari tuturan mahasiswa saat melakukan presentasi di kelas. Setelah data diambil, data kemudian dianalisis dalam beberapa tahap yaitu identifikasi, klasifikasi, deskripsi dan interprestasi. Berikut adalah hasil analisis data yang didapat.

Data 1 diambil dari kelas $\mathrm{A}$, tuturan mahasiswa 1A:

"Before we start the presentation, we are going to introduce our member"

Tuturan di atas mengandung modalitas intensional. Modalitas intensional adalah modalitas yang berisi kehendak, harapan, anjuran, atau permintaan. Tuturan di atas mengandung penanda leksikal "are going to" (akan) yang menyatakan kehendak, yaitu kehendak untuk memperkenalkan anggota grup presentasi. Dengan penutur menyatakan kehendaknya dengan kata "akan", tuturan di 
atas dikategorikan sebagai modalitas intensional.

Data 2 diambil dari kelas A, tuturan mahasiswa $2 \mathrm{~A}$.

"Alright, that's all for our group. We will give you time to understand and read what we have share, you have to read it in 5 minutes".

Tuturan di atas mengandung modalitas epistemik. Modalitas epistemik merupakan modalitas atau ungkapan yang berisi dan merefleksikan unsur kemungkinan, keteramalan, keharusan dan kepastian. Dalam tuturan di atas, terdapat kata "have to" (harus) sehingga tuturan di atas menyatakan "keharusan" bagi mitra tutur untuk membaca materi yang telah dibagikan dalam 5 menit.

Data 3 diambil dari kelas $\mathrm{A}$, tuturan mahasiswa $3 \mathrm{~A}$.

"Analysis in Morphology cannot be compared to analysis in syntax. The two are different. What I can explain is morphology focus on structure of word, syntax on sentence.

Dari tuturan di atas dapat diambil kesimpulan bahwa modalitas dalam kalimat di atas adalah modalitas dinamik. Modalitas dinamik adalah modalitas yang menyatakan kemampuan. Penanda leksikal modalitas dinamik terdapat dalam kata "can" (bisa), yang menyatakan kemampuan. Dalam tuturan ini, mahasiswa mencoba menjelaskan kemampuannya dalam menjelaskan perbedaan analisis dalam sintaksis dan morfologi.

Data 4 diambil dari kelas $\mathrm{A}$, tuturan mahasiswa $4 \mathrm{~A}$.

"I want to present about findings discussion"

Tuturan di atas mengandung modalitas intensional, yaitu modalitas yang menyatakan keinginan. Tuturan di atas menyatakan keinginan penutur untuk mempresentasikan hasil temuan diskusi dalam presentasi. Pendana leksikal modalitas intensional dalam tuturan tersebut adalah "want" (ingin).

Data 5 diambil dari kelas A, tuturan mahasiswa $5 \mathrm{~A}$.

"Well, I think that's all we can explain. Thank you for your attention and see you"
Dari tuturan di atas dapat diambil kesimpulan bahwa modalitas dalam tuturan di atas adalah modalitas dinamik. Modalitas yang menyatakan kemampuan. Penanda leksikalnya terdapat dalam kata "can" (bisa), yang menyatakan kemampuan. Dalam tuturan ini, mahasiswa mencoba menjelaskan bahwa berikut adalah hal-hal yang dapat mereka jelaskan selama presentasi.

Data 6 diambil dari kelas B, tuturan mahasiswa $1 \mathrm{~B}$.

"Okay class, today I want to present our material about bilingualism".

Dalam kalimat ini terdapat modalitas intensional dengan kata "want" (ingin) sebagai penanda leksikal. Modalitas intensional merupakan modalitas yang menyatakan keinginan. Dengan menggunakan leksikal marker "want" (ingin), penutur jelas menyatakan keinginannya untuk menjelaskan materi mengenai bilingualism"

Data 7 diambil dari kelas B, tuturan mahasiswa $2 \mathrm{~B}$

"Language learner can be bilingual or multilingual", "We can be bilingual or multilingual"

Tuturan di atas mengandung modalitas dinamik. Penanda leksikal "can" (bisa) menjadi penanda dalam tuturan ini yang menunjukkan modalitas. Modalitas dalam kalimat ini menyatakan kemampuan penutur dan mitra tutur sebagai penutur bahasa, dapat menjadi bilingual ataupun multilingual

Data 8 diambil dari kelas $\mathrm{B}$, tuturan mahasiswa 3B.

"Permission to answer first question. In my opinion, children who are just learning English do not have to understand grammar first because it will make them difficult to speak"

Modalitas intensional terdapat dalam tuturan di atas. Modalitas intensional merupakan modalitas yang berisi tentang sesuatu hal yang berisi kehendak, harapan, anjuran, ataupun permintaan. Tuturan di atas menunjukan permintaan atau izin untuk menjawab pertanyaan dalam presentasi.

Data 9 diambil dari kelas $\mathrm{B}$, tuturan mahasiswa 4B. 
"The previous theory that I just explained was failed to explain what goes on inside our mind".

Dari kalimat tersebut terdapat modalitas dinamik, modalitas yang menyatakan kemampuan. Dalam kalimat tersebut di atas dapat dilihat pada penanda leksikal "failed"/ "gagal", menyatakan ketidakmampuan. Kata gagal menyiratkan modalitas yang ada pada kalimat tersebut.

Data 10 diambil dari kelas $\mathrm{B}$, tuturan mahasiswa 5B.

"Yes, you can learn and master any

language that you want, if you want".

Tuturan di atas mengandung modalitas dinamik, dengan penanda leksikal "can" (bisa) selain modalitas yang menyatakan kemampuan, dalam kalimat tersebut juga dapat dirasakan modalitas epistemik, yaitu modalitas yang menyatakan kemungkinan. Refleksi kemungkinan terdapat dalam kata "if you want" (jika kamu inginkan) selain menyatakan kemampuan kata tersebut juga dapat menyiratkan kemungkinan.

Data 11 diambil dari kelas $\mathrm{B}$, tuturan mahasiswa 6B.

"Maybe it will be good for the child to imitate the good language that he got from the environment".

Dengan penanda leksikal 'mungkin", sudah cukup menyatakan faktor kemungkinan dalam kalimat. Jadi, dalam kalimat ini menggunakan modalitas epistemik. Modalitas epistemik adalah sikap pembicara yang didasari oleh keyakinan atau kekurangyakinan terhadap kebenaran proposisi.

Data 12 diambil dari kelas $\mathrm{B}$, tuturan mahasiswa 5B

"The most important think that I want to tell you guys, is that if you want to master a language, you need to get good input, and then you have to practice the language.".

Kalimat tersebut memiliki modalitas intensional karena di dalamnya menyiratkan keinginan. Alasannya adalah karena bahasa digunakan untuk menyatakan sikap pembicara sehubungan dengan peristiwa nonaktual yang diungkapkannya. Bagi pendengar atau teman pembicara, hal itu berarti bahwa apa yang diutarakan pembicara itu merupakan dorongan untuk mengaktualisasikan peristiwa yang bersangkutan. Dalam tuturan ini, modalitas intensional dapat dilihat melalui penanda leksikal "want and need" (ingin dan perlu) yang menyatakan 'keinginan'.

Data 13 diambil dari kelas $\mathrm{B}$, tuturan mahasiswa 6B.

"Yeah, once again I will tell you guys, good input is important in language learning".

Penanda modalitas intensional tersebut tergambarkan melalui penanda leksikal "will tell" yang merupakan opini yang menyatakan keinginan untuk menyatakan pendapat.

\section{KESIMPULAN}

Demikianlah hasil analisis tuturan mahasiswa dalam presentasi di kelas. Modalitas yang digunakan adalah modalitas intensional (yang menggambarkan tentang keinginan), lalu yang kedua adalah modalitas epistemik, modalitas yang menyatakan tentang kemungkinan. Sedang kategori ketiga yang penulis temukan adalah modalitas dinamik, dan tipe modalitas terakhir adalah modalitas deontik. Keempat modalitas tersebut membantu kita dalam memahami suatu situasi/proposisi/situasi. Presentasi merupakan media bagi mahasiswa untuk menyatakan pendapat dan pengetahuannya mengenai halhal yang ingin disampaikan, hal tersebut tentunya juga merefleksikan dan tak lepas dari pendapat-pendapat pribadi mengenai hal yang sedang diberi pendapat atau disampaikan. Dalam suatu opini terdapat penjabaran akan kemampuan dan juga harapan atau keinginan.

Hasil temuan dari penelitian menjadi sebuah kontribusi dalam pembelajaran, khususnya kontribusi bagi mahasiswa dalam mengelola tuturan ketika kelas presentasi.

\section{REFERENSI}

Aisyah, S. N. (2019). Modalitas Bahasa Indonesia dalam Talk Show Mata Najwa. Belajar Bahasa, 4(2).

Chaer, A. (1994). Linguistik Umum. Rineka Cipta. 
Comrie, B. (1976). Aspect, an introduction to the study of verbal aspect and related problems. Cambridge university press.

Desi, S. P. (2017). Penerapan Metode Presentasi Ilmiah Berbasis Poster untuk Meningkatkan Ketrampilan Berbicara Siswa Kelas V Sekolah Dasar. Antologi UPI, 5(1), 280-289.

Faisal, S. (1992). Format-format Penelitian Sosial . Rajawali Press.

Kumalasari, D. M. A. S. M. N. (2020). Analisis Modalitas dalam Ilmu Semantik pada Film My Name is Khan. ISLLAC, 4(2).

Moleong, L. J. (1999). Metodologi Penelitian Kualitatif. Remaja Posdakarya.

Palmer, F. R. (1981). Semantics. Cambridge University Press.

Risaldi, A. dkk. (2021). Modalitas sebagai Fitur Lingual Praktik Kuasa dalam Komunitas Pedofilia. KEMBARA:, 7(2).

Saeed, J. I. (2000). Semantics. Blackwell publishing.

Sari, A. A. (2017). Komunikasi Antarpribadi. Deepublish (Grup Penerbitan CV Budi Utama).

Sudaryanto. (2015). Metode dan Aneka Teknik Analisis Bahasa . Duta Wacana University.

Wiryanto. (2004). Pengantar Ilmu Komunikasi. Grasindo.

http://repository.usu.ac.id/bitstream/12345678 9/19368/7/.pdf http://hal.archivesouvertes.fr/docs/00/33/91/54/PDF/tensori al_logic.pdf,

http://jos.oxfordjournals.org/content/25/3/221. extract, 